\title{
Opini Audit dan Kinerja Keuangan Pemerintah Daerah dengan Realisasi PAD sebagai Pemediasi
}

\author{
Ni Made Dwi Pradnyani ${ }^{1}$ \\ Fakultas Ekonomi dan Bisnis \\ Universitas Udayana, Indonesia
}

\author{
Ni Putu Sri Harta Mimba² \\ Fakultas Ekonomi dan Bisnis \\ Universitas Udayana, Indonesia
}

Surel : pradnyani.dwi@gmail.com

\section{ABSTRAK}

Tujuan penelitian ini adalah untuk mengetahui pengaruh opini audit pada kinerja keuangan Pemerintah Daerah Kabupaten/Kota di Provinsi Bali dengan pendapatan asli daerah sebagai pemediasi yang didasarkan pada teori legitimasi (letimacy theory). Penelitian ini dilakukan pada Pemerintah Daerah Provinsi Bali tahun 2013-2017. Teknik analisis data yang digunakan adalah analisis jalur path (path analysis). Hasil analisis menemukan bahwa opini audit berpengaruh positif pada pendapatan asli daerah. Hal ini menunjukkan bahwa opini audit yang baik cenderung akan meningkatkan sumber daya yang diberikan masyarakat daerah. Opini audit berpengaruh positif pada kinerja keuangan Pemerintah Daerah Kabupaten/Kota di Provinsi Bali. Realisiasi PAD berpengaruh positif pada kinerja keuangan Pemerintah Daerah Kabupaten/Kota di Provinsi Bali tahun 2013-2017. Realisasi pendapatan asli daerah merupakan variabel pemediasi hubungan opini audit dengan kinerja keuangan pemerintah daerah.

Kata Kunci: Opini Audit; Pendapatan Asli Daerah; Kinerja Keuangan Pemerintah Daerah.

Audit Opinion and Local Government Financial Performance with Realization of PAD as Mediator

\footnotetext{
ABSTRACT

The purpose this study was determine effect of audit opinion on the financial performance District / City Governments in Bali Province with local revenue as mediator based on legitimacy theory. This research was conducted at Provincial Government of Bali in 2013-2017 using the saturated sample method. Data analysis technique used path analysis. Analysis found that audit opinion had a positive effect on local own-source revenue. Shows that good audit opinion tends to increase the resources provided by local community specifically regional original income. Audit opinion has positive effect on the financial performance of District / City Governments in Bali Province in 2013-2017. Realization PAD has positive effect on financial performance of District / City Governments in Bali Province in 2013-2017. The realization of regional own-source revenue mediating variable in the relationship between audit opinion and local government financial performance.

Keywords: Audit Opinion; Local Revenue; Local Government Financial Performance.
}

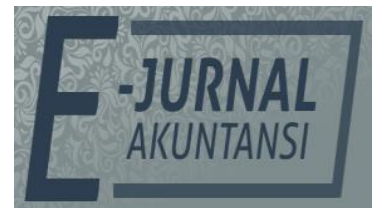

e-ISSN 2302-8556

Vol. 30 No. 12

Denpasar, Desember 2020

Hal. 3150-3161

DOI:

10.24843/EJA.2020.v30.i12.p12

PENGUTIPAN:

Pradnyani, N.M.D. \& Mimba, N.P.S.H. (2020).

Opini Audit dan Kinerja

Keuangan Pemerintah

Daerah dengan Realisasi

PAD sebagai Pemediasi. EJurnal Akuntansi, 30(12),

3150-3161

RIWAYAT ARTIKEL:

Artikel Masuk: 17 Juli 2020

Artikel Diterima: 9 Desember 2020

Artikel dapat diakses : https://ojs.unud.ac.id/index.php/Akuntansi/index 


\section{PENDAHULUAN}

Opini audit atas LKPD diasumsikan berfungsi sebagai dasar legitimasi yang diberikan oleh pihak-pihak yang berkepentingan terhadap Pemerintah Daerah, khususnya masyarakat daerah. Ketika opini audit sesuai dengan harapan masyarakat maka hal tersebut akan berdampak pada meningkatnya sumber daya masyarakat yang diberikan kepada Pemerintah Daerah, khususnya dalam bentuk pajak daerah dan retribusi daerah (Pendapatan Asli Daerah / PAD), sehingga dapat dikatakan bahwa opini audit berpengaruh positif terhadap pencapaian realisasi pendapatan Pemerintah Daerah, khususnya PAD (Marfiana, N., Kurniasih, 2018). Selanjutnya, sebagaimana hasil penelitin sebelumnya (Mustikarini, W. A., \& Fitriasari, 2012) menunjukkan bahwa realisasi pendapatan berpengaruh terhadap kinerja Pemerintah Daerah. Hal ini mengindikasikan bahwa realisasi pendapatan daerah dapat menjadi pemediasi pengaruh opini audit terhadap kinerja Pemerintah Daerah.

Penelitian-penelitian terdahulu terkait opini audit terhadap kinerja keuangan pemerintah daerah di Indonesia hasilnya masih beragam. Diantaranya (Masdiantini \& Erawati, 2016) dalam penelitiannya membuktikan bahwa opini audit berpengaruh terhadap kinerja keuangan pemerintah daerah. Hal ini tidak sejalan dengan penelitian yang dilakukan oleh (Cherrya, 2013) yang membuktikan bahwa opini audit tidak berpengaruh terhadap kinerja keuangan Pemerintah Daerah. Hasil penelitian yang masih beragam terkait opini audit tersebut yang mendorong penulis untuk meneliti kembali pengaruh opini audit terhadap kinerja keuangan pemerintah daerah.

Legitimasi organisasi umumnya digambarkan sebagai kondisi perilaku organisasi yang sejalan dengan harapan pihak-pihak di sekitar organisasi tersebut menjalankan aktivitasnya (Suchman, 1995), sehingga kesesuaian ataupun ketidaksesuaian organisasi dalam menjalankan fungsi dan tanggungjawabnya akan berkonsekuensi terhadap legitimasi serta kinerja dan pencapaian tujuan organisasi tersebut. Atas dasar asumsi tersebut maka teori legitimasi semakin banyak digunakan dalam penelitian akuntansi dan audit, terutama yang terkait dengan pengungkapan informasi publik (Michael K.Power, 2003), termasuk dalam menjelaskan fungsi audit pada Pemerintah Daerah (Bukti peran laporan audit terhadap tingkat legitimasi masyarakat terhadap Pemerintah Daerah dibuktikan oleh (Claudio Ferraz, 2008) dalam penelitiannya di Brazil. Hasil penelitiannya menunjukkan bahwa hasil audit atas korupsi pada Pemerintahan Daerah yang dipublikasikan kepada masyarakat memberikan dampak terhadap keterpilihan kembali.

Berbeda dengan penelitian sebelumnya yang dilakukan oleh (Masdiantini \& Erawati, 2016) terkait opini audit, pada penelitian ini peneliti menggunakan variabel mediasi atas pengaruh opini audit pada kinerja keuangan Pemerintah Daerah yang berupa variabel tingkat pencapaian realisasi pendapatan daerah yang sepengetahuan penulis masih relatif jarang dilakukan oleh penelitian sebelumnya, khususnya di Provinsi Bali.

Opini audit atas LKPD diasumsikan berfungsi sebagai dasar legitimasi yang diberikan oleh pihak-pihak yang berkepentingan terhadap Pemerintah Daerah, khususnya masyarakat daerah. Dimana, legitimasi tersebut merupakan keyakinan anggota masyarakat untuk menaati dan menerima segala bentuk 
kebijakan yang dibuat oleh penguasa serta memenuhi segala tuntutan yang ada dalam rezim penguasa tersebut. Legitimasi merupakan sebuah konsep yang melahirkan hubungan antara pemimpin dan masyarakat yang dipimpinya. Sehingga dapat diasumsikan bahwa, ketika opini audit sesuai dengan harapan masyarakat maka hal tersebut akan berdampak pada meningkatnya sumber daya masyarakat yang diberikan kepada Pemerintah Daerah, khususnya dalam bentuk pajak daerah dan retribusi daerah (Pendapatan Asli Daerah / PAD), sehingga dapat dikatakan bahwa opini audit berpengaruh positif terhadap pencapaian realisasi pendapatan Pemerintah Daerah, khususnya PAD. Hal ini sejalan dengan penelitian yang dilakukan (Marfiana, N., Kurniasih, 2018) menunjukkan bahwa opini audit berpengaruh positif terhadap pencapaian realiasasi PAD. Berdasarkan hal tersebut, maka rumuskan hipotesis sebagai berikut.

$\mathrm{H}_{1}$ : Opini audit berpengaruh positif pada realiasasi Pendapatan Asli Daerah.

Opini merupakan pernyataan profesional sebagai kesimpulan pemeriksaan mengenai tingkat kewajaran informasi yang disajikan dalam laporan keuangan. Seperti halnya di sektor swasta, laporan keuangan dikatakan baik apabila mendapatkan opini WTP (Budiarto, 2007). Untuk mendapatkan opini tersebut, terdapat empat kriteria yang harus diperhatikan, yaitu pertama kepatuhan terhadap standar akuntansi, kedua efektivitas pengendalian internal, ketiga kepatuhan terhadap peraturan perundang-undangan dan keempat kecukupan pengungkapan. Untuk mendapatkan opini yang baik diperlukan motivasi dan komitmen dari semua jenjang pegawai mulai dari tingkat bawah sampai tingkat yang paling atas sehingga tidak terdapat hal-hal material yang menyimpang dari ketentuan yang ada. Selain hal tersebut, opini BPK dapat pula menjadi tolok ukur (indikator) untuk menilai akuntabilitas sebuah entitas pemerintah. Opini ini dapat menaikkan ataupun menurunkan tingkat kepercayaan pemangku kepentingan atas pelaporan yang disajikan oleh pihak yang diaudit, dalam hal ini entitas pemerintah daerah. Dengan kata lain, semakin baik opini audit BPK maka seharusnya dapat menunjukkan semakin membaiknya kinerja suatu pemerintah daerah. Hal tersebut didukung oleh penelitian (Virgasari, 2009) dan (Masdiantini \& Erawati, 2016) menunjukkan bahwa terdapat hubungan positif antara opini audit BPK terhadap kinerja keuangan pemerintah daerah. Dari uraian tersebut, maka dapat dikembangkan hipotesis.

$\mathrm{H}_{2}$ : Opini audit berpengaruh positif pada kinerja keuangan Pemerintah Daerah Kabupaten/Kota di Provinsi Bali tahun 2013-2017.

PAD merupakan kekayaan riil dari masing-masing daerah. PAD sendiri bersumber dari pajak daerah, retribusi daerah, hasil pengelolaan kekayaan daerah yang dipisahkan, dan lain-lain PAD yang sah. Untuk membiayai kebutuhan daerah, pemerintah daerah terlebih dahulu menggunakan PAD agar memperkecil ketergantungan dana dari pemerintah pusat. Diberlakukannya otonomi daerah membuat pemerintah daerah memiliki kesempatan untuk memberdayakan seluruh potensi guna memperoleh PAD yang tinggi.

PAD yang tinggi dapat mengindikasikan bahwa pemerintah daerah telah melakukan upaya yang optimal dalam menggali sumber-sumber PAD sehingga meningkatkan kemandirian daerahnya (Himran et al., 2013). Peningkatan dari 
PAD seharusnya didukung dengan peningkatan kualitas layanan publik dan pembangunan infrastruktur yang baik. Dimana, pelayanan publik dan infrasktruktur yang baik mengindikasikan kinerja yang baik dari suatu Pemda. Peningkatan PAD merupakan faktor pendukung dari kinerja ekonomi makro, pertumbuhan yang positif mendorong adanya invetasi sehingga sehingga secara bersama investasi tersebut akan mendorong adanya perbaikan infrastruktur sarana dan prasarana daerah. Infrastruktur yang baik tentunya akan meningkatkan kinerja dari pemerintah daerah. Hal ini sejalan dengan penelitian yang dilakukan oleh (Cherrya, 2013) dan (Julitawati, Ebit, Darwanis, 2012) yang membuktikan bahwa PAD berpengaruh terhadap kinerja keuangan Pemerintah Daerah.

$\mathrm{H}_{3}$ : Realisiasi PAD berpengaruh positif pada kinerja keuangan Pemerintah Daerah Kabupaten/Kota di Provinsi Bali tahun 2013-2017.

Legitimasi terhadap organisasi akan terbentuk ketika terdapat kondisi perilaku organisasi yang sejalan dengan harapan pihak-pihak di sekitar organisasi tersebut menjalankan aktivitasnya (Suchman, 1995). Ketika terdapat ketidaksesuaian antara harapan pihak-pihak sekitar dengan capaian organisasi akan berkonsekuensi pada berkurangnya legitimasi terhadap organisasi tersebut, yang mana hal tersebut dapat berdampak pada berkurangnya aliran sumber daya yang diterima oleh organisasi serta berdampak buruk pada pencapaian tujuan organisasi, begitupula sebaliknya. Karenanya penting bagi organisasi untuk merancang dan mengelola kelembagaan organisasi dalam rangka melindungi ataupun menjaga legitimasi.

Terkait dengan fungsi dan tanggungjawab yang diemban oleh Pemerintah Daerah, maka untuk mendukung penyelenggaraan aktivitasnya, pemerintah daerah membutuhkan legitimasi dari Pemerintah dan masyarakat sebagai stakeholders utamanya. Legitimasi dari Pemerintah diperlukan untuk meningkatkan dukungan dalam pelaksanaan program-program di daerah, sedangkan legitimasi dari masyarakat dibutuhkan oleh Pemerintah daerah karena selain untuk mendukung kelancaran aktivitas pemerintahan, juga agar masyarakat dapat berperan aktif dalam pembangunan di daerah, misalnya dengan cara membayar pajak/retribusi daerah ataupun Pendapatan Asli Daerah (PAD) lainnya. Dalam rangka meningkatkan legitimasi Pemerintah dan masyarakat terhadap Pemerintah Daerah, jika berdasarkan (Michael K.Power, 2003) yang menyatakan bahwa dengan semakin besarnya tuntutan atas transparansi dan akuntabilitas organisasi saat ini maka audit berperan penting dalam memproduksi legitimasi dan hasil penelitian (Claudio Ferraz, 2008) yang menemukan adanya pengaruh hasil audit atas korupsi pada Pemerintahan Daerah terhadap keterpilihan kembali petahana maka dapat dikatakan bahwa keberadaan opini audit akan menjadi salah satu penentu bagi terciptanya legitimasi Pemerintah dan Masyarakat. Ketika opini audit atas LKPD dapat menggambarkan akuntabilitas yang tinggi atas pengelolaan sumber daya yang dilakukan Pemerintah Daerah maka hal tersebut akan mendorong Masyarakat untuk meningkatkan sumber daya yang diberikan kepada Pemerintah Daerah, yang mana hal ini diwujudkan dengan semakin meningkatnya pencapaian realisasi pendapatan daerah, khususnya yang bersumber dari masyarakat dalam bentuk PAD. 
Jika dikatkan dengan hasil penelitian sebelumnya, khususnya (Mustikarini, W. A., \& Fitriasari, 2012) yang menemukan bahwa realisasi PAD berpengaruh positif terhadap kinerja Pemerintah Daerah maka dapat disimpulkan bahwa realisasi PAD dapat berperan sebagai pemediasi atas pengaruh opini audit terhadap kinerja, yang mana ketika opini audit baik maka dapat meningkatkan realisasi PAD, dan atas peningkatan realisasi PAD tersebut akan berdampak pada peningkatan kinerja yang dicapai oleh Pemerintah Daerah Oleh karena itu, hipotesisnya dapat dirumuskan sebagai berikut.

$\mathrm{H}_{4}$ : Opini Audit berpengaruh positif pada kinerja Pemerintah Daerah Kabupaten/Kota di Provinsi Bali tahun 2013-2017 dengan dimediasi oleh pencapaian realisasi Pendapatan Asli Daerah.

\section{METODE PENELITIAN}

Lokasi dari penelitian ini yaitu Biro Keuangan Provinsi Bali dan Badan Pemeriksa Keuangan Republik Indonesia. Sementara ruang lingkup dari penelitian ini adalah Kabupaten/Kota se-Provinsi Bali. Obyek dalam penelitian ini adalah opini audit, realisasi Pendapatan Asli Daerah dan kinerja keuangan Pemerintah Daerah.

Populasi dalam penelitian ini adalah Pemerintah Daerah Kabupaten dan Kota se-Provinsi Bali tahun 2013-2017. Sampel yang digunakan dalam penelitian ini adalah seluruh anggota populasi yakni, LRA kabupaten dan kota se-Provinsi Bali tahun 2013-2017, yang terdiri dari 8 kabupaten dan 1 kota dengan kurun waktu 5 tahun (2013-2017) dan opini audit pemerintah Kabupaten/Kota di Provinsi Bali yang terdapat dalam IHPS II Tahun 2017.

Analisis Jalur Path (Path Analysis) digunakan untuk pengujian pengaruh simultan (efek langsung dan tidak langsung) sebuah variabel terhadap variabelvariabel lain. Berikut adalah rumus struktural dari analisis jalur sebagai berikut.

Substruktur I:

$\mathrm{Y} 1=\mathrm{b} 1 \mathrm{X} 1+\varepsilon_{1}$

Substruktur II:

$\mathrm{Y} 2=\mathrm{b} 2 \mathrm{X} 1+\mathrm{b} 3 \mathrm{Y} 2+\varepsilon_{2}$

\section{HASIL DAN PEMBAHASAN}

Statistik deskriptif dalam penelitian ini disajikan untuk memberikan informasi mengenai karakteristik variabel-variabel penelitian, antara lain minimum, maksimum, mean, dan standar deviasi. Pengukuran rata-rata (mean) merupakan cara yang paling umum digunakan untuk mengukur nilai sentral dari suatu distribusi data. Sedangkan, standar deviasi merupakan perbedaan nilai data yang diteliti dengan nilai rata-ratanya. Hasil statistik deskriptif pada penelitian ini ditunjukkan pada Tabel 1.

Tabel 1. Hasil Uji Statistik Deskriptif

\begin{tabular}{lccccc}
\hline \multicolumn{1}{c}{ Variabel } & $\mathrm{N}$ & Minimum & Maximum & Mean & Std. Deviasi \\
\hline Opini Audit & 45 & 1.00 & 4.00 & 3.0444 & .97597 \\
Realisasi PAD & 45 & 23.25 & 28.46 & 25.4983 & 1.28875 \\
Kinerja Keuangan & 45 & 1.08 & 2.38 & 1.9126 & .38551 \\
Pemerintah Daerah & & & & & \\
\hline
\end{tabular}

Sumber: Data Penelitian, 2019 
Berdasarkan Tabel 1, dapat dilihat nilai minimum untuk opini adalah 1 dan nilai maksimumnya adalah 4. Mean untuk jumlah opini audit adalah 3,04, hal ini berarti rata-rata nilai opini audit sebesar 3,04. Standar deviasinya 0,97, hal ini berarti terjadi penyimpangan nilai opini audit terhadap nilai rata-ratanya yaitu sebesar 0,97. Variabel realisasi PAD nilai minimumnya adalah 23,25 dan nilai maksimumnya adalah 28,46. Mean variabel realisasi PAD adalah 23,25, hal ini berarti bahwa rata-rata raliasasi PAD sebesar 23,25. Standar deviasinya sebesar 1,28, hal ini berarti terjadi penyimpangan nilai realisasi PAD terhadap nilai rata-ratanya sebesar 1,28 . Variabel kinerja keuangan nilai minimumnya adalah 1,08 dan nilai maksimumnya adalah 2,38. Mean variabel kinerja keuangan adalah 1,91, hal ini berarti rata-rata kinerja keuangan sebesar 1,91. Standar deviasinya sebesar 0,38 , hal ini berarti terjadi penyimpangan nilai kinerja keuangan pemerintah terhadap nilai rata-ratanya sebesar 0,38 .

Uji asumsi klasik yang harus dipenuhi pada analisis regresi linear sederhana antara lain Uji Normalitas, Uji Multikolenearitas dan Uji Heteroskedastisitas.

Tabel 2. Hasil Uji Asumsi Klasik

\begin{tabular}{lcccc}
\hline \multicolumn{1}{c}{ Variabel } & Sig. & Tolerance & VIF & Keterangan \\
\hline Uji Kolmogorov-Smirnov & 0.900 & & & Berdistribusi Normal \\
Uji Multikolinearitas & & & & \\
$\begin{array}{l}\text { Opini Audit } \\
\text { Realisasi PAD }\end{array}$ & & 0.836 & 1.196 & Bebas multikol \\
Uji Heteroskedastisitas & & 0.836 & 1.196 & Bebas multikol \\
Opini Audit & 0.883 & & & $\begin{array}{c}\text { Bebas } \\
\text { healisasi PAD }\end{array}$ \\
heteroskedastisitas \\
Bebas \\
heteroskedastisitas
\end{tabular}

Sumber: Data Penelitian, 2019

Uji normalitas bertujuan untuk menguji apakah dalam model regresi, variabel pengganggu atau residual memiliki distribusi normal atau tidak. Suatu model regresi dikatakan memiliki data normal atau mendekati normal jika koefisien Asymp. sig (2-tailed) lebih besar dari $a=0,05$. Berdasarkan Tabel 2, hasil uji normalitas dengan uji Kolmogorov-Smirnov diperoleh nilai sig 0,900 untuk unstandarized residu lebih besar dari $\alpha=0,05$ artinya, data telah berdistribusi normal.

Metode untuk mengetahui adanya multikolinearitas dalam model regresi adalah terlihat dari nilai tolerance dan variance inflation factor (VIF). Pada Tabel 2, disajikan hasil perhitungan nilai tolerance dan VIF kurang dari angka 10 dan angka tolerance lebih dari 0,1 menggunakan program SPSS. Tabel 2, menunjukkan bahwa tidak ada variabel bebas yang nilai tolerance lebih dari 0,1 atau VIF kurang dari 10, maka disimpulakan bahwa tidak ada multikolinearitas antara variabel bebas dalam model regresi.

Uji heterokedastisitas dalam penelitian ini dilakukan dengan menggunakan uji Glejser. Apabila Asymp. Sig ( $p$ value) $>0,05$ maka dapat disimpulkan tidak terjadi heterokedastisitas. Berdasarkam Tabel 2, dapat diketahui bahwa semua variabel memiliki Asymp. Sig ( $p$ value) $>0,05$, artinya pada model regresi tidak terdapat heteroskedastisitas. 
Untuk pemeriksaan terhadap asumsi ini, dapat dilakukan dengan melihat susunan model teoritis yang telah dibangun dengan memperlihatkan bentuk hubungan antar variabel adalah linier, yaitu sistem aliran ke satu arah, dimana hubungan antara $e_{i}$ saling bebas demikian juga hubungan antara $e_{i}$ dengan variabel $x$ saling bebas, dan tidak ada variabel endogen yang mempunyai pengaruh bolak balik.

Di dalam analisis jalur, pengaruh langsung dinyatakan dengan koefisien $\rho_{i}$, sedangkan pengaruh tidak langsung dan pengaruh total dapat dihitung dengan membuat perhitungan tersendiri. Untuk pendugaan parameter dilakukan dengan analisis regresi melalui software SPSS 15.0 for Windows diperoleh hasil sebagai berikut.

Substruktur 1: $Y=\beta_{1} X+\varepsilon_{1}$

Dari hasil perhitungan pada pengujian data diperoleh hasil sebagai berikut.

Tabel 3. Coefficients Substruktur 1

\begin{tabular}{lcccc}
\hline \multicolumn{1}{c}{ Variabel } & $\begin{array}{c}\text { Unstandardized } \\
\text { Beta }\end{array}$ & $\begin{array}{c}\text { Standardized } \\
\text { Beta }\end{array}$ & $\begin{array}{c}\text { Std. } \\
\text { Error }\end{array}$ & $\begin{array}{c}\text { Nilai } \\
\text { Sig. }\end{array}$ \\
\hline Constanta & 23.870 & & 0.588 & 0,000 \\
Opini Audit & 0.535 & 0.405 & 0,184 & 0,006 \\
\hline
\end{tabular}

Sumber: Data Penelitian, 2019

Untuk Substruktur 2 di dapat persamaan sebagai berikut: $\mathrm{Y}_{2}=\beta_{1} \mathrm{X}+\beta_{2} \mathrm{Y}_{1}+\varepsilon_{2}$

Dari hasil perhitungan pada pengujian data diperoleh hasil sebagai berikut.

Tabel 4. Coefficients Substruktur 2

\begin{tabular}{lcccc}
\hline \multicolumn{1}{c}{ Variabel } & $\begin{array}{c}\text { Unstandardized } \\
\text { Beta }\end{array}$ & $\begin{array}{c}\text { Standardized } \\
\text { Beta }\end{array}$ & $\begin{array}{c}\text { Std. } \\
\text { Error }\end{array}$ & $\begin{array}{c}\text { Nilai } \\
\text { Sig. }\end{array}$ \\
\hline Constanta & 0.379 & & 0.153 & 0.017 \\
Opini Audit & 0.384 & 0.972 & 0.008 & 0.000 \\
Realiasasi PAD & 0.014 & 0.048 & 0.006 & 0.029 \\
\hline
\end{tabular}

Sumber: Data Penelitian, 2019

Berdasarkan perhitungan terhadap substruktur 1, dan 2, maka dapat diketahui besarnya pengaruh langsung, pengaruh tidak langsung dan pengaruh total antar variabel. Perhitungan pengaruh antar variabel adalah sebagai berikut.

Besarnya pengaruh variabel opini audit terhadap realisasi pendapatan asli daerah secara parsial, dilihat dari nilai beta atau Standardized Coefficient adalah sebagai berikut.

Pengaruh variabel opini audit terhadap realisasi pendapatan asli daerah.

$$
\mathrm{X}_{1} \longrightarrow \mathrm{Y}_{1}=0,405
$$

Pengaruh variabel realisasi pendapatan asli daerah terhadap kinerja keuangan pemerintah daerah.

$$
\mathrm{Y}_{1} \longrightarrow \mathrm{Y}_{2}=0,048
$$

Pengaruh variabel opini audit terhadap kinerja keuangan pemerintah daerah.

$$
\mathrm{X}_{1} \longrightarrow \mathrm{Y}_{2}=0,972
$$

Pengaruh variabel opini audit terhadap kinerja keuangan pemerintah daerah melalui realisasi pendapat asli daerah.

$$
\mathrm{X}_{1} \rightarrow \mathrm{Y}_{1} \rightarrow \mathrm{Y}_{2}=(0,405 \times 0,048)=0,019
$$

Pengaruh total (Total effect).

Pengaruh total $=$ pengaruh langsung + pengaruh tidak langsung 


$$
\begin{aligned}
& =(0,972+0,048)+0,019 \\
& =1,039
\end{aligned}
$$

Persamaan struktural untuk model penelitian ini adalah :

Substruktur 1:

$$
\begin{aligned}
Y= & \beta_{1} X+\varepsilon_{1} \\
& Y=0,405 X+e \\
& \text { Pengaruh error }(\text { Pei })=\sqrt{ } 1-R^{2} \\
& \text { Pei }=\sqrt{1}-0,164=\sqrt{ } 0,836=0,914
\end{aligned}
$$

Substruktur 2:

$$
\begin{aligned}
& Y_{2}= \beta_{1} X+\beta_{2} Y 1+\varepsilon_{2} \\
& Y_{2}=0,972 X+0,048 Y_{1}+e
\end{aligned}
$$

Pengaruh error $($ Pei $)=\sqrt{ } 1-\mathrm{R}^{2}$

Pei $=\sqrt{ } 1-0,984=\sqrt{ } 0,016=0,167$

Ada dua indikator untuk melakukan pemeriksaan validitas model, yaitu koefisien determinasi total dan theory triming dimana hasilnya dapat disajikan sebagai berikut.

Hasil koefisien determinasi total:

$$
\begin{aligned}
& \mathrm{R}^{2}{ }_{\mathrm{m}}=1-(1-0,164)(1-0,454) \\
& \mathrm{R}^{2}=1-0,456 \\
& \mathrm{R}^{2}{ }_{\mathrm{m}}=0,543
\end{aligned}
$$

Artinya, keragaman data yang dapat dijelaskan oleh model adalah sebesar 54,3 persen atau dengan kata lain informasi yang terkandung dalam data sebesar 54,3 persen dapat dijelaskan oleh model, sedangkan sisanya yaitu 45,6 persen dijelaskan oleh variabel lain (tidak terdapat dalam model) dan error.

Pendekatan ini dilakukan dengan membuang jalur-jalur yang non signifikan agar memperoleh model yang benar-benar didukung oleh data empirik. Uji validasi pada setiap jalur untuk pengaruh langsung adalah sama dengan regresi, menggunakan nilai $\mathrm{p}$ dari uji $\mathrm{t}$ yaitu pengujian koefisien regresi variabel dibakukan secara parsiil dengan nilai opini audit $(X)$ terhadap realisasi pendapatan asli daerah $\left(Y_{1}\right)$ adalah 2,905 sig 0,006. Sedangkan opini audit $(X)$ terhadap kinerja keuangan pemerintah $\left(\mathrm{Y}_{2}\right)$ adalah 45,926 dengan sig 0,000. dan realisasi PAD $\left(\mathrm{Y}_{1}\right)$ terhadap kinerja keuangan pemerintah daerah $\left(\mathrm{Y}_{2}\right)$ sebesar 2,264 dengan sig 0,029 .

Kriteria pengujian untuk menjelaskan interpretasi pengaruh antar masing-masing variabel yakni apabila nilai signifikansi < level of significance 5 persen, maka $\mathrm{H}_{0}$ ditolak dan $\mathrm{H}_{1}$ diterima. Sebaliknya, jika nilai signifikansi > level of significance 5 persen maka $\mathrm{H}_{0}$ diterima dan $\mathrm{H}_{1}$ ditolak. Sedangkan, untuk variabel pemediasi $\mathrm{Z}$ hitung haruslah $>$ dari $\mathrm{Z}$ tabel pada tingkat signifikansi 0.05. Hasil Uji t disajikan pada Tabel 5, berikut.

Berdasarkan hasil analisis pada Tabel 5, diperoleh taraf signifikansi penelitian untuk variabel Opini audit terhadap realiasasi Pendapatan Asli Daerah sebesar 0,006 $<0,05$ sehingga $\mathrm{H}_{0}$ ditolak dan $\mathrm{H}_{1}$ diterima, dengan kata lain Opini audit berpengaruh positif pada realiasasi Pendapatan Asli Daerah.

Berdasarkan hasil analisis pada Tabel 5, diperoleh taraf signifikansi penelitian untuk variabel opini audit terhadap kinerja keuangan sebesar 0,000 < 0,05 sehingga $\mathrm{H}_{0}$ ditolak dan $\mathrm{H}_{2}$ diterima, dengan kata lain, opini audit 
mempunyai pengaruh positif dan signifikan terhadap kinerja keuangan pemerintah.

Tabel 5. Hasil Uji Hipotesis (Uji t)

\begin{tabular}{lccc}
\hline \multicolumn{1}{c}{ Variabel } & Sig. uji t & Syarat & Keterangan \\
\hline $\begin{array}{l}\text { (Constant) } \\
\text { Opini Audit pada Realiasasi }\end{array}$ & 0.006 & $<5 \%$ & $\mathrm{H}_{1}=$ Diterima \\
$\begin{array}{l}\text { PAD } \\
\text { Opini Audit pada Kinerja }\end{array}$ & 0.000 & $<5 \%$ & $\mathrm{H}_{2}=$ Diterima \\
$\begin{array}{l}\text { Keuangan Pemerintah Daerah } \\
\text { Realiasasi PAD pada Kinerja } \\
\text { Keuangan Pemerintah Daerah }\end{array}$ & 0.029 & $<5 \%$ & $\mathrm{H}_{3}=$ Diterima \\
& & $>\begin{array}{c}\text { Z table } \\
\text { pada }\end{array}$ & $\mathrm{H}_{4}=$ Diterima \\
$\begin{array}{l}\text { Opini Audit pada Kinerja } \\
\text { Keuangan Pemeritah dengan } \\
\text { Realisasi PAD sebagai }\end{array}$ & 412,47 & $\begin{array}{c}\text { tingkat } \\
\text { Pemediasifikasi }\end{array}$ & \\
& & 0,05 yaitu \\
1,96 & \\
\hline
\end{tabular}

Sumber: Data Penelitian, 2019

Berdasarkan hasil perhitungan diperoleh taraf signifikansi penelitian untuk variabel realisasi PAD terhadap kinerja keuangan pemerintah daerah sebesar 0,029 < 0,05 sehingga $\mathrm{H}_{0}$ ditolak dan $\mathrm{H}_{3}$ diterima, dengan kata lain Realisiasi PAD berpengaruh positif pada kinerja keuangan Pemerintah Daerah Kabupaten/Kota di Provinsi Bali tahun 2013-2017.

Pengaruh tidak langsung Opini Audit Terhadap Kinerja Keuangan Pemerintah Daerah Melalui Realisasi Pendapatan Asli Daerah

Menghitung nilai $S_{a b}$

$\mathrm{S}_{\mathrm{ab}}=\sqrt{b^{2} s a^{2}+a^{2} s b^{2}+s a^{2} s b^{2}}$

$S_{a b}=\sqrt{(0,0001 * 0,03)+(0,28 * 0,000036)+(0,033 * 0,000036)}$

$S_{a b}=0,00018$

Menghitung nilai $a b$

$\mathrm{ab}=0,535 \times 0,014$

$\mathrm{ab}=0,00749$

Menghitung nilai $Z$

$\mathrm{Z}=\frac{a b}{\mathrm{Sab}}$

$Z=\frac{0,00749}{0,00018}$

$\mathrm{Z}=412,47$

Berdasarkan hasil perhitungan diperoleh $Z_{\text {hitung }}$ sebesar $412,47>Z_{\text {tabel }}$ sebesar 1,96 sehingga $\mathrm{H}_{0}$ ditolak dan $\mathrm{H}_{4}$ diterima, dengan kata lain bahwa realisasi pendapat asli daerah merupakan variabel pemediasi hubungan opini audit dengan kinerja keuangan pemerintah daerah.

\section{SIMPULAN}

Opini audit berpengaruh positif pada realiasasi Pendapatan Asli Daerah. Sehingga dapat diasumsikan bahwa, ketika opini audit sesuai dengan harapan 
masyarakat maka hal tersebut akan berdampak pada meningkatnya sumber daya masyarakat yang diberikan kepada Pemerintah Daerah, khususnya dalam bentuk pajak daerah dan retribusi daerah (Pendapatan Asli Daerah / PAD).

Opini audit berpengaruh positif pada kinerja keuangan Pemerintah Daerah Kabupaten/Kota di Provinsi Bali tahun 2013-2017. Hal ini menunjukkan bahwa opini audit BPK dapat menjadi tolok ukur (indikator) untuk menilai akuntabilitas sebuah entitas pemerintah. Opini ini dapat menaikkan ataupun menurunkan tingkat kepercayaan pemangku kepentingan atas pelaporan yang disajikan oleh pihak yang diaudit, dalam hal ini entitas pemerintah daerah (Li et al, 2009). Dengan kata lain, semakin baik opini audit BPK maka dapat menunjukkan semakin membaiknya kinerja suatu pemerintah daerah.

Realisiasi PAD berpengaruh positif pada kinerja keuangan Pemerintah Daerah Kabupaten/Kota di Provinsi Bali tahun 2013-2017. PAD yang tinggi dapat mengindikasikan bahwa pemerintah daerah telah melakukan upaya yang optimal dalam menggali sumber-sumber PAD sehingga meningkatkan kemandirian daerahnya (Himran et al., 2013). Peningkatan dari PAD seharusnya didukung dengan peningkatan kualitas layanan publik dan pembangunan infrastruktur yang baik. Dimana pelayanan publik dan infrasktruktur yang baik mengindikasikan kinerja yang baik dari suatu Pemda

Realisasi pendapat asli daerah merupakan variabel pemediasi hubungan opini audit dengan kinerja keuangan pemerintah daerah. Ketika opini audit atas LKPD dapat menggambarkan akuntabilitas yang tinggi atas pengelolaan sumber daya yang dilakukan Pemerintah Daerah maka hal tersebut akan mendorong Masyarakat untuk meningkatkan sumber daya yang diberikan kepada Pemerintah Daerah, yang mana hal ini diwujudkan dengan semakin meningkatnya pencapaian realisasi pendapatan daerah, khususnya yang bersumber dari masyarakat dalam bentuk PAD.

Penelitian selanjutnya disarankan melakukan analisis yang lebih mendalam terhadap peran mediasi pendapatan atas pengaruh opini audit terhadap kinerja Pemerintah Daerah dengan menggunakan jenis pendapatan lainnya, misalnya analisis terhadap jenis-jenis PAD seperti pajak daerah dan retribusi.

\section{REFERENSI}

Ahmad, Abd.R., Alan Farley \& Moonsamy Naidoo. (2012). Analysis of Government-University Relationship from the Perspective of Agency Theory. Journal of Education and Practice.3(6)

Akai, N. and Sakata, M. (2002). Fiscal Decentralization Contributes to Economic Growth: Evidence form State-Level Cross-Section Data for the United States. Journal of Urban Economics, 52, pp: 93-108.

Amagoh, Francis \&Aloysius Ajab Amin. (2012). An Examination of the Impacts of Fiscal Decentralization on Economic Growth. International Journal of Business Administration, 3(6), pp: 72-81.

Badrudin, Rudy. (2011). Effect of Fiscal Decentralization on Capital Expenditure, Growth, and, Welfare. Economic Journal of Emerging Markets, 3(3), pp: 211223.

Budiarto, Bambang. 2007. Pengukuran Keberhasilan Pengelolaan Keuangan Daerah. Seminar Ekonomi Daerah. Surabaya. 
Budianto, Wendy. (2012). Pengaruh opini, temuan audit, dan gender terhadap kinerja penyelenggaraan pemerintah daerah kabupaten/kota di indonesia 2008-2010. Skripsi Sarjana. FEUI. Depok.

Bodman, P., Kelly Ana Heaton and Andrew Hodge. (2009). Fiscal Decentralisation and Economic Growth: A Bayesian Model Averaging Approach. MRG@UQ Discussion Paper, School of Economics, University of Queensland.

Cherrya Dhia. (2013). Analisis Pengaruh Pendapatan Asli Daerah Terhadap Kinerja Keuangan Pada Pemerintah Kabupaten dan Kota di Provinsi SumateraSelatan. Jurnal ilmiah STIE MDP. Volume 2. Nomer 1.

Connolly, Anne Therese, Cara Marie De Leoz, Miguel Gorospe, And Marajella Sebastian. (2014). Determinants of Having A High Human Development Index.A Qualitative Analysis on Human Development Of Countries All Over The World.

Davoodi, Hamid. \& Heng-fu Zou. (1998). Fiscal Decentralization and Economic Growth: A Cross-Country Study. Journal of Urban Economics, 43, pp: 244257.

Erlina. (2008). Metodologi Penelitian Bisnis: Untuk Akuntansi dan Manajemen. Edisi kedua. Medan: USU Press.

Endah, Wahyuningsih. (2016). Pengaruh Pendapatan Asli Daerah (PAD) dan Dana Perimbangan terhadap Kinerja Keuangan Pemerintah Daerah. Ejurnal Akuntansi Universitas Muhammadiyah Surakarta.

Ferraz, C., Finan, F., (2014). Exposing corrupt politicians: the effect of Brazil's publicly released audits on electoral outcomes. Quarterly Journal of Econmics, 123 (2), 703-745.

Faridi, M. Zahir. (2011). Contribution of Fiscal Decentralization to Economic Growth: Evidence from Pakistan. Pakistan Journal of Social Sciences (PJSS), 31(1), pp: 1-33.

Fisman, Raymond. \& Roberta Gatti. (2002). Decentralization and Corruption: Evidence across Countries. Journal of Public Economics, 83, pp: 325-345.

Giroux, G., \& Shields, D. (1993). Accounting controls and bureaucratic strategies in municipal government. Journal of Accounting and Public Policy, 12 (3), 239-262

Govinda Rao, M. (2003). Fiscal Decentralization in China And India: A Comparative Perpspective.Asia-Pacific Development Journal.10(1). Halim, Abdul. (2007). Akuntansi Sektor Publik: Akuntansi Keuangan Daerah. Jakarta: Penerbit Salemba Empat.

Halim, Abdul dan Muhammad Syam Kusufi. (2014). Akuntansi Sektor Publik: Teori, Konsep, dan Aplikasi Akuntansi Sektor Publik dari Anggaran hingga Laporan Keuangan, dari Pemerintah hingga Tempat Ibadah. Edisi 2. Jakarta: Salemba Empat.

Halim, Abdul dan Syukriy Abdullah. (2006). Hubungan dan Masalah Keagenan di Pemerintahan Daerah: sebuah peluang penelitian anggaran dan akuntansi. JurnalAkuntansi Pemerintah, 2(1), pp: 53-64.

Himran, Yofandi Koleangan, Rosalina A M Kawung. (2013). Analisis Kinerja Keuangan Dan Efektifitas Pengelolaan Di Kabupaten Banggai. Jurnal Fakultas Ekonomi dan Bisnis Universitas Sam Ratulang, 3(4), pp:104-110. 
Jensen, M. dan Meckling, W. (1976). Theory of The Firm: Managerial Behaviour, Agency Costs and Ownership Structure. Journal of Financial Economics, 3(4), pp: 305-360.

Julitawati, Ebit, Darwanis, Jalaluddin. 2012. Pengaruh Pendapatan Asli Daerah dan Dana Perimbangan terhadap Kinerja Keuangan Pemerintah. Jurnal Akuntansi Pascasarjana Universitas Syiah Kuala Lumpur, Vol.1, No.1.

Kusumawardani, Meidia. (2012). Pengaruh Size, Kemakmuran, Ukuran Legislatif, Leverage Terhadap Kinerja Keuangan Pemerintah Daerah di Indonesia.Accounting Analysis Journal Universitas Negeri Semarang, 1(1):27:35.

Masdiantini, Ni Made Adi Erawati. (2016). Pengaruh Ukuran Pemerintah Daerah, Kemakmuran, Intergovernmental, Revenue, Temuan dan Opini Audit BPK pada Kinerja Keuangan. E-Jurnal Akuntansi Universitas Udayana, 10(2), 456-473.

Marfiana, N., \& Kurniasih, L. (2018). Pengaruh karakteristik pemerintah daerah dan hasil pemeriksaan audit BPK terhadap kinerja keuangan pemerintah daerah kabupaten/kota. Sustainable Competitive Advantage (SCA), 3(1).

Mercy, Pricilia Suoth. (2013). Kinerja Dinas Pendapatan Daerah dalam Pengelolaan Pendapatan Asli Daerah di Kota Bitung. Jurnal EMBA 1203. Universitas Sam Ratulangi Manado,1(3):1203-1211.

Mirna, Sesotyaningtyas. (2012). Pengaruh Leverage, Ukuran Legislatif, Intergovernmental Revenue dan Pendapatan Pajak Daerah Terhadap Kinerja Keuangan Pemerintah Daerah. Accounting Analysis Journal. Universitas Negeri Semarang, 1(1):1-6.

Mustikarini, W. A., \& Fitriasari, D. (2012). Pengaruh karakteristik pemerintah daerah dan temuan audit BPK terhadap kinerja pemerintah daerah kabupaten/kota di Indonesia tahun Anggaran 2007. Simposium Nasional Akuntansi XV, Banjarmasin.

Nur, Lailatul Khasanah. (2014). Pengaruh Karakteristik, Kompleksitas, dan Temuan Audit Terhadap Tingkat Pengungkapan Laporan Keuangan Pemerintah Daerah (Studi pada LKPD Kabupaten/Kota Provinsi Jawa Tengah Periode 2010-2012). Diponegoro Journal Of Accounting, 3(3):1-11.

Power, M. (2003). Auditing and the production of legitimacy. Accounting, Organizations and Society, 28, 379-394.

Virgasari, Aviva. 2009. Hubungan antara Opini Auditor pada Laporan Keuangan Daerah, Pendapatan Asli Daerah, dan Dan Alokasi Umum dengan Kinerja Keuangan Daerah. Skripsi.Universitas Brawijaya Malang. 